\title{
Efektivitas Pembelajaran E-Learning \\ Pelatihan Dasar Calon Pegawai Negeri Sipil di Badan Siber dan Sandi Negara
}

\author{
Ratri Nur Rohmah \\ Pusat Pendidikan dan Pelatihan Badan Siber dan Sandi Negara \\ email: ratri.nih@gmail.com
}

\begin{abstract}
Abstrak
Perkembangan teknologi dan munculnya pandemi covid-19 menjadi pemicu utama diterapkannya pembelajaran jarak jauh dalam pelaksanaan Pelatihan Dasar Calon Pegawai Negeri Sipil di BSSN. Salah satu metode yang diterapkan dalam Pelatihan Dasar CPNS ini adalah pembelajaran online atau yang dikenal dengan e-learning. Meskipun penerapan metode elearning ini berbeda dengan metode klasikal yang diterapkan sebelumnya, namun melalui elearning diharapkan kegiatan pembelajaran dapat tetap berjalan efektif, sehingga kegiatan tersebut dapat mencapai tujuan pembelajaran yang telah ditetapkan. Penelitian ini mengungkapkan gambaran efektivitas pembelajaran e-learning pada Latihan Dasar CPNS. Metode yang digunakan adalah kualitatif deskriptif. Pengumpulan data dilakukan dengan observasi, wawancara serta studi literatur. Wawancara dilakukan kepada pengelola, penyelenggara, pengajar dan peserta diklat. Hasil penelitian menunjukkan bahwa e-learning Pelatihan Dasar CPNS dapat berjalan secara efektif. Hal ini terlihat dari beberapa indikator keberhasilan proses pembelajaran yang telah dicapai. Data yang diperoleh juga menunjukkan pembelajaran berhasil mencapai tujuan instruksional yang telah ditetapkan, mampu memberikan pengalaman belajar yang atraktif, mampu melibatkan peserta secara aktif, dan sarana-sarana yang menunjang proses belajar mengajar terpenuhi dengan baik. Selain itu juga didapatkan hasil bahwa model synchronous lebih diminati peserta dari pada asynchronous. Menurut peserta model synchronous dapat membantu untuk lebih fokus saat belajar dan mampu meningkatkan motivasi saat belajar. Untuk perbaikan pelaksanaan e-learning di masa mendatang disarankan untuk memperbanyak penyampaian materi dengan metode synchronous dan penambahan aplikasi gamifikasi agar pembelajaran lebih menarik.
\end{abstract}

Keywords: efektivitas, pembelajaran, e-learning

\begin{abstract}
Technology and covid-19 pandemic have become the main trigger for implementation of distance learning in Basic Training Civil Servants at BSSN. E-learning has many differences compared to the conventional methods that were applied previously. We hoped e-learning activities running well so they can achieve the learning objectives. This study seeks to reveal an overview of the effectiveness of e-learning Basic Training Civil Servants. The method used in this research is descriptive qualitative research. Data collection was carried out by observation, interview, and literature study methods. Interviews were conducted with managers, administrators, teachers, and training participants. Based on the research, the results are e-learning Basic Training Civil Servants run effectively. This is indicated by learning indicators effectiveness that has been
\end{abstract}


achieved. Data shows that learning has succeeded in achieving the set instructional goals, can provide an attractive learning experience, can actively involve participants, and the facilities that support the teaching and learning process are fulfilled properly. Besides, it was also found that the synchronous model was more attractive to participants than asynchronous. Participants feel that synchronous model can help them focus more and increase motivation when learning. To improve the implementation of online learning in the future, it is suggested to increase synchronous methods and deliver material through gamification application to make learning more interesting.

Keywords: effectiveness, learning, e-learning

(C) 2020 Pusdiklat Perdagangan. All rights reserved

\section{PENDAHULUAN Latar Belakang}

Pelatihan Dasar Calon Pegawai Negeri Sipil (Latsar CPNS) merupakan bagian penting dalam menyiapkan Aparatur Sipil negara (ASN) sebagai abdi negara. Latsar CPNS menjadi prasyarat bagi calon ASN yang akan diangkat menjadi Pegawai Negeri Sipil. Hal ini sesuai dengan Peraturan Pemerintah Nomor 11 Tahun 2017 tentang Manajemen Pegawai Negeri Sipil yang menyebutkan bahwa persyaratan untuk dapat diangkat dalam jabatan pelaksana diantaranya adalah telah mengikuti dan lulus pelatihan terkait dengan bidang tugas dan/ atau lulus pendidikan dan pelatihan terintegrasi.

Pengertian pelatihan yang selanjutnya disebut prajabatan atau saat ini dikenal dengan nama Latsar CPNS merupakan proses pelatihan untuk membangun integritas moral, kejujuran, semangat dan motivasi nasionalisme dan kebangsaan, karakter kepribadian yang unggul dan bertanggung jawab, dan memperkuat profesionalisme serta kompetensi bidang bagi calon PNS pada masa percobaan terintegrasi (Republik Indonesia, 2017). Hal ini diperkuat LAN (2018) bahwa CPNS wajib menjalani Masa Prajabatan.

Terdapat beberapa target kompetensi sesuai dengan agenda yang diterapkan pada pelaksanaan Latsar CPNS ini. Kompetensi tersebut meliputi kemampuan menunjukkan sikap perilaku bela negara, mengaktualisasikan nilai-nilai dasar PNS dalam pelaksanaan tugas jabatannya, mengaktualisasikan kedudukan dan peran PNS dalam kerangka Negara Kesatuan Republik Indonesia, dan menunjukkan penguasaan kompetensi teknis yang dibutuhkan sesuai dengan bidang tugas.

Selama mengikuti Latsar CPNS, para peserta dibekali berbagai macam pengetahuan dasar agar pada saat bekerja memiliki pola pikir dan perilaku sebagai ASN yang berkarakter dan profesional. Bekal tersebut meliputi pengetahuan dan kemampuan teknis yang sifatnya umum maupun substansial sebagai modal dasar dalam melaksanakan tugas di tempat kerjanya masing-masing.

Pelaksanaan pembelajaran Latsar CPNS dibagi menjadi beberapa agenda meliputi agenda Sikap Perilaku Bela Negara, agenda Nilai-Nilai Dasar PNS, agenda Kedudukan dan Peran PNS dalam NKRI, dan agenda Habituasi. Setiap agenda wajib diikuti peserta agar mampu memahami dan mempraktikkan berbagai ilmu yang diterima selama proses pembelajaran, sehingga upaya untuk mempersiapkan ASN yang profesional dan berkarakter dapat tercapai.

Seiring dengan kemajuan teknologi, maka pelaksanaan kegiatan pelatihan juga mengalami penyesuaian. Hal ini diperkuat dengan munculnya pandemi covid-19 yang mulai merebak di Indonesia sejak awal tahun 2020. Penyesuaian yang dilakukan diantaranya adalah pemanfaatan media digital dalam kegiatan pembelajaran. Salah satu alternatif solusi yang dapat diterapkan untuk tetap melaksanakan kegiatan pembelajaran Latsar CPNS ini adalah menerapkan pembelajaran blended learning yang menggabungkan pembelajaran secara klasikal dan nonklasikal. Pelaksanaan pembelajaran non klasikal 
dilakukan secara online learning atau e-learning.

\section{E-learning}

Rahman et al., (2020) menyimpulkan bahwa proses pembelajaran secara e-learning sudah cukup efektif dan mampu berperan dalam mendukung proses peningkatan kemampuan peserta dalam memahami beberapa mata pelatihan dalam Latsar CPNS. Suharsono (2020) mengungkapkan bahwa pembelajaran Latsar CPNS melalui metode e-learning dapat berjalan dengan lancar dan dapat mencapai tujuan dengan baik.

Hartley (2001) mendefisikan e-learning adalah suatu jenis belajar mengajar yang memungkinkan tersampaikannya bahan ajar ke peserta dengan menggunakan media internet, intranet atau media jaringan komputer lain. Sedangkan Rosenberg (2001) menyebutkan e-learning merujuk pada penggunaan teknologi internet untuk mengirimkan serangkaian solusi yang dapat meningkatkan pengetahuan dan keterampilan.

Sementara itu, fokus utama dalam pembelajaran e-learning menurut Chusna (2019) adalah siswa atau peserta didik, dimana siswa dituntut mandiri terhadap waktu tertentu, bertanggung jawab dalam pelaksanaan pembelajarannya, dan "memaksa" siswa memainkan peranan yang lebih aktif dalam pembelajarannya. Hal ini sangat berbeda dengan pembelajaran yang konvensional yang bersifat teacher center yaitu guru dianggap sebagai sumber ilmu atau seseorang yang serba tahu dan ditugaskan untuk menyalurkan ilmu pengetahuan kepada peserta didik atau siswa.

Metode pembelajaran e-learning memiliki beberapa keunggulan. Hal ini yang menyebabkan model pembelajaran tersebut banyak digunakan di berbagai penyelenggaraan pendidikan dan pelatihan. Sesuai yang diungkapkan oleh Malik et al. (2017) bahwa teknologi online menjadi peluang dalam pembelajaran karena dapat diakses oleh peserta secara maksimal kapan saja dan di mana saja. Selain itu dalam pembelajaran e-learning banyak menggunakan perlengkapan multimedia sehingga mampu menampilkan berbagai macam data baik tulisan, audio, video, aplikasi dan sebagainya, sehingga membuat pembelajaran lebih menarik.

Keuntungan lain dari pembelajaran e-learning adalah dapat diikuti oleh peserta dengan jumlah yang besar. Pembelajaran ini juga memiliki kemudahan dalam pemanfaatan sumber daya seperti yang diungkap Taplin (2013) bahwa pembelajaran online menjadi hal yang perlu dipertimbangkan karena dapat digunakan sebagai sarana untuk meningkatkan pengajaran, membangun fleksibilitas dalam pelajar, menjangkau instruksi, dan mengurangi biaya instruksi.

Manfaat lain yang dapat diambil dari pelaksanaan pembelajaran e-learning seperti yang disampaikan oleh Pranoto (2009) meliputi:

a. meningkatkan daya serap peserta atas materi yang diajarkan;

b. meningkatkan partisipasi aktif dari peserta;

c. meningkatkan kemampuan belajar mandiri peserta;

d. meningkatkan kualitas materi pendidik dan pelatihan;

e. meningkatkan kemampuan menampilkan informasi dengan perangkat teknologi informasi, dimana dengan perangkat biasa sulit dilakukan.

E-learning tidak hanya memberikan nilai positif pada peserta, tetapi juga memberikan kemudahan pada pengajar. Pengajar mendapat berbagai fasilitas baru dalam penyampaian materi atau sharing informasi. Selain itu pengajar juga dapat menampilkan materi menggunakan bantuan teknologi dengan lebih menarik. Masing-masing pihak yang berkepentingan dalam e-learning tersebut dapat memanfaatkannya dengan optimal jika mampu memahami karakteristik elearning tersebut dengan baik.

Pendapat yang lain tentang keunggulan elearning diungkapkan dengan memperhatikan fungsinya. Menurut Munir (2017) media pembelajaran memiliki tiga fungsi 
pembelajaran digital di dalam kegiatan pembelajaran, yaitu sebagai suplemen, komplemen, dan substitusi. Fungsi sebagai suplemen (tambahan) yaitu pembelajar mempunyai kebebasan memilih, apakah akan memanfaatkan materi pembelajaran elektronik atau tidak. Fungsi sebagai komplemen (pelengkap), yaitu materi pembelajaran elektronik diprogramkan untuk melengkapi materi pembelajaran yang diterima pembelajar di dalam kelas. Fungsi substitusi yaitu pembelajar diberi beberapa alternatif model kegiatan pembelajaran agar dapat menyesuaikan dengan kebutuhan.

Sementara itu keunggulan e-learning terlihat dari beberapa hal yang tersedia padanya. Elearning memiliki keunggulan dalam beberapa aspek seperti stability, security, reliability and responsiveness, ease of use, user-friendliness, organization, and personalization seperti pada parameter efektivitasnya (Tseng, 2011).

Pada dasarnya e-learning memiliki dua tipe yaitu synchronous dan asynchronous. Kedua tipe tersebut tidak ada tatap muka yang dilakukan secara fisik. Namun demikian dalam proses pembelajaran tetap dibutuhkan keberadaan pengajar, bahan ajar, aplikasi bahan ajar, dan media pembelajaran lainnya. Yang membedakan hanya lokasi dan waktu saat pembelajaran berlangsung. Pada synchronous dilakukan secara langsung atau live serta real-time. Hal yang perlu diperhatikan dalam tipe pembelajaran ini menurut Clark (2007) sebagai berikut "The roots of synchronous e-learning are derived from three main influences: the classroom, the media, and the conference". Sementara itu asynchronous dapat dilakukan secara lebih bebas dari sisi waktu dan tempat yang digunakan dalam pembelajaran.

Dengan memperhatikan keunggulan serta manfaat dalam pembelajaran e-learning, maka penyelenggaraan kegiatan Latsar CPNS tahun 2020 di Pusdiklat BSSN menerapkan model pembelajaran blended learning dengan mengombinasikan antara pembelajaran konvensional dan penerapan teknologi komputer dalam bentuk e-learning. Latsar CPNS menjadi pilot project yang menerapkan model pembelajaran e-learning dengan memanfaatkan Learning Management System (LMS) maupun media dan aplikasi lain untuk mendukung proses pembelajaran. $\mathrm{Hal}$ ini didukung kondisi lingkungan adanya pandemi Covid-19 yang belum berakhir. Sehingga model pembelajaran ini menjadi pilihan prioritas pada pelaksanaan Latsar CPNS.

Meskipun model pembelajaran yang diterapkan pada Latsar CPNS berbeda dengan pelaksanaan sebelumnya, namun diharapkan pembelajaran dapat berjalan secara efektif. Oleh karena itu penyelenggaraan Latsar PNS yang telah berjalan perlu dilakukan evaluasi untuk mengetahui keberhasilannya. Selanjutnya berdasarkan hasil evaluasi dapat dijadikan sebagai masukan dalam pengambilan keputusan untuk penyelenggaraan Latsar CPNS di masa berikutnya.

Terdapat beberapa referensi model evaluasi yang dapat diterapkan. Model evaluasi CIPP merupakan salah satu alternatif yang dapat digunakan untuk melakukan evaluasi program pembelajaran. Model evaluasi CIPP merupakan sebuah model evaluasi yang menggunakan pendekatan yang bororientasi pada manajemen atau disebut sebagai bentuk evaluasi manajemen program (Mahmudi, 2011). Dalam evalusi CIPP menggunakan empat unsur yaitu context, input, process dan product.

Model evaluasi program pembelajaran yang lain adalah Kirk Patrick. Evaluasi terhadap program pelatihan menurut Kirk Patrick dikenal dengan istilah Four Levels Evaluation yang mencakup empat level evaluasi yaitu level 1 reaction, level 2 learning, level 3 behaviour, dan level 4 result (Badu, 2012).

Firman (1987) mengungkapkan bahwa keefektifan program pembelajaran diketahui berdasarkan beberapa variabel berikut:

a. berhasil menghantarkan siswa mencapai tujuan instruksional yang telah ditetapkan;

b. memberikan pengalaman belajar yang atraktif;

c. melibatkan siswa secara aktif sehingga menunjang pencapaian tujuan instruksional. 


\section{d. memiliki sarana-sarana yang menunjang proses belajar mengajar.}

Pada penelitian ini, penulis menggunakan variabel tersebut sebagai indikator dalam mendeskripsikan efektivitas pembelajaran elearning pada Latsar CPNS sesuai dengan tujuan penelitian ini.

\section{METODOLOGI}

Metode yang digunakan dalam penelitian ini adalah kualitatif deskriptif. Sebagaimana yang diungkapkan Sugiyono (2012) metode penelitian kualitatif adalah metode penelitian yang berlandaskan pada filsafat postpositivisme yang biasanya digunakan untuk meneliti pada kondisi objektif yang alamiah dimana peneliti berperan sebagai instrumen kunci. Sedangkan penelitian deskriptif merupakan metode yang berfungsi untuk mendeskripsikan atau memberi gambaran terhadap objek yang diteliti melalui data atau sampel yang telah terkumpul sebagaimana adanya, tanpa melakukan analisis dan membuat kesimpulan yang berlaku umum.

Dalam penelitian ini penulis mengumpulkan data dari berbagai sumber baik data primer maupun data sekunder. Data primer dikumpulkan melalui metode observasi, wawancara serta survei. Sedangkan data sekunder didapatkan melalui studi literatur dan dokumen.

Kegiatan pengamatan dilakukan oleh penulis selama proses pembelajaran. Pengamatan ini tidak hanya berfokus pada pencapaian peserta dari sisi pengembangan knowledge, namun juga terhadap pencapaian skill dan attitude yang ditunjukkan.

Metode lain yang digunakan untuk memperkaya data dalam penelitian adalah dengan melakukan wawancara. Penulis melakukan wawancara dengan peserta, penyelenggara maupun pengelola Latsar CPNS sebagai narasumber. Sedangkan untuk mendapatkan informasi lainnya yang lebih mendalam penulis melakukan wawancara pada penyelenggara untuk menghimpun data pendukung lainnya.
Dalam penelitian ini penulis juga memberikan kuesioner kepada peserta Latsar CPNS sebagai populasi yang telah menerapkan model pembelajaran e-learning pada saat mengikuti Latsar CPNS. Adapun jumlah keseluruhan peserta Latsar CPNS dengan model pembelajaran e-learning ini adalah 40 orang. Dalam pengumpulan data penulis memberikan kuesioner kepada seluruh anggota populasi atau dengan menggunakan metode pengambilan sampel jenuh. Sedangkan media yang digunakan dalam penyebaran kuesioner berupa google form.

Pertanyaan dalam kuesioner disampaikan dengan model jawaban yang disajikan menggunakan skala likert. Level jawaban meliputi lima tingkatan yang tersedia seperti tabel 1. Dengan menggunakan skala likert akan mempermudah penulis dalam melakukan pengolahan data serta analisisnya.

Adapun indikator yang digunakan dalam mengukur efektivitas pembelajaran meliputi keberhasilan dalam menghantarkan siswa mencapai tujuan instruksional yang telah di tetapkan, kemampuan dalam memberikan pengalaman belajar yang atraktif, kemampuan melibatkan siswa secara aktif sehingga menunjang pencapaian tujuan instruksional, dan ketersediaan sarana-sarana dalam menunjang proses belajar mengajar (Firman, 1987).

Tabel 1. Skala Likert

\begin{tabular}{|l|c|}
\hline \multicolumn{1}{|c|}{ Tingkatan } & Disingkat \\
\hline Sangat Tidak Setuju & STS \\
\hline Tidak Setuju & TS \\
\hline Netral & $\mathrm{N}$ \\
\hline Setuju & S \\
\hline Sangat Setuju & SS \\
\hline
\end{tabular}

Sumber: Sugiyono (2012)

Selanjutnya data yang telah terkumpul diolah dengan menggunakan tabulasi sederhana. Tabulasi adalah penyusunan data dalam bentuk tabel. Pabundu (2005) mengatakan maksud pembuatan tabel-tabel ini adalah menyederhanakan data agar mudah melakukan analisis sehingga dapat ditarik kesimpulan. Dengan demikian kesimpulan mengenai efektivitas pelaksanaan 
pembelajaran e-learning pada Latsar CPNS tersebut dapat tergambar dengan jelas.

\section{HASIL DAN PEMBAHASAN}

Dalam rangka memenuhi kebutuhan kompetensi ASN, maka pembelajaran yang diterapkan pada e-learning Latsar CPNS dilakukan dengan kombinasi berbagai macam metode pembelajaran. Salah satu strategi dalam pelaksanaan pembelajaran ini adalah dengan memetakan materi dan metode yang cocok dalam penyampaiannya. Dalam pelaksanaannya, beberapa materi yang perlu penekanan khusus dilaksanakan dengan metode klasikal di lokasi pelatihan Pusdiklat BSSN pada tahap awal Latsar CPNS. Kegiatan tersebut meliputi pembukaan pelatihan yang dilanjutkan pengarahan program. Pelaksanaan kegiatan dilakukan di dalam aula dengan mematuhi protokol kesehatan di era pandemi Covid-19. Setelah itu kegiatan pembelajaran dilakukan secara online dari berbagai lokasi dengan memanfaatkan teknologi yang ada.

Dalam pelaksanaannya, pembelajaran elearning Latsar CPNS mengombinasikan dua tipe pembelajaran yaitu penerapan metode synchronous dan asynchronous. Metode synchronous dilakukan secara tatap muka langsung pada waktu-waktu khusus yang telah dijadwalkan sesuai dengan agenda pembelajaran yang telah direncanakan. Adapun aplikasi yang digunakan pada tatap muka online ini adalah media pertemuan online seperti zoom, google meet, microsoft team dan media lain yang sejenis.

Pada tatap muka online tersebut penyampaian materi dilakukan dengan metode ceramah, diskusi, brainstorming, tanya jawab secara langsung. Metode gamifikasi juga dilakukan saat pembelajaran dilakukan secara tatap muka secara online dengan memanfaatkan kahoot, quizizz maupun google form. Hal ini berdampak peserta cenderung lebih aktif berpartisipasi dalam kegiatan pembelajaran. Selain itu peserta juga merasa tertarik selama proses pembelajaran berlangsung.

Sedangkan penerapan metode asynchronous pada Latsar CPNS dilakukan dengan memanfaatkan Learning Management System
(LMS) berupa aplikasi moodle. Materi pelatihan berupa modul, bahan tayang, bahan ajar, video maupun sumber belajar lainnya diunggah di dalam aplikasi tersebut. Peserta pelatihan dapat dengan leluasa mempelajari materi yang disajikan oleh pengampu mata pelatihan secara mandiri.

Pada saat menerapkan metode asynchronous, proses pembelajaran menemui kemudahan dan tantangan. Kelebihan yang dialami dalam penerapan asynchronous adalah dari aspek ketersedian materi yang digunakan selama proses pembelajaran. Materi dapat diakses oleh peserta kapanpun dan dimanapun berada, sehingga lebih fleksibel dalam memanfaatkannya. Sedangkan tantangan yang dihadapi yaitu komunikasi antara pengajar dengan peserta dirasa kurang interaktif.

Selain itu, media yang digunakan untuk kegiatan belajar adalah media chat dalam bentuk telegram maupun whatsapp. Aplikasi tersebut digunakan untuk mewadahi jika terdapat materi yang perlu didiskusikan di luar waktu tatap muka yang telah dijadwalkan, sehingga peserta tetap dapat melakukan diskusi meskipun di luar jadwal yang ditetapkan.

Berbagai jenis metode dan aplikasi diterapkan pada Latsar CPNS dengan maksud untuk memenuhi kebutuhan sarana pembelajaran secara lengkap. Dengan pemenuhan sarana diharapkan proses pembelajaran dapat berjalan dengan efektif dan tujuan pembelajaran dapat tercapai.

Adapun gambaran mengenai efektivitas pembelajaran ini dapat diketahui berdasarkan data yang diperoleh selama penelitian. Data yang telah terkumpul menunjukkan bahwa pembelajaran e-learning pada Latsar CPNS dapat berjalan secara efektif. Hal ini dapat diketahui melalui hasil survei yang secara rinci menginformasikan beberapa hal yang dapat dicapai dalam pembelajaran e-learning Latsar CPNS sesuai indikator efektivitas pembelajaran sebagai berikut: 


\section{a. Pencapaian tujuan pembelajaran}

Untuk mengetahui pencapaian tujuan pembelajaran e-learning pada Latsar CPNS dapat dilihat pada gambar 1 .



Gambar 1. Pencapaian tujuan pembelajaran

Berdasarkan gambar 1 dapat diketahui bahwa tujuan pembelajaran pada Latsar CPNS yang dilaksanakan secara e-learning dapat tercapai. Hal ini terlihat dari data dari responden yang menunjukkan bahwa $5 \%$ netral, $71 \%$ setuju dan $24 \%$ sangat setuju terhadap pernyataan bahwa tujuan pembelajaran e-learning pada Latsar CPNS tercapai.

Pembelajaran e-learning yang diterapkan pada Latsar CPNS berjalan dengan lancar tanpa mengalami kendala yang siginifikan. Kegiatan selama pembelajaran dapat menyesuaikan dengan agenda yang telah ditetapkan. Pencapaian tujuan pembelajaran ini juga tergambar berdasarkan data lain melalui wawancara yang menunjukkan bahwa peserta mampu mencapai berbagai indikator hasil pembelajaran yang telah ditetapkan dengan baik. Setiap kompetensi yang tercantum dalam kurikulum mampu dilampaui sesuai levelnya mulai dari pemahaman serta penerapannya. Salah satu bentuk pencapaian tujuan pembelajaran dari aspek pemahaman peserta terhadap materi pembelajaran dapat diketahui melalui salah satu kegiatan pengambilan nilai yang dilakukan dalam bentuk post test yang menghasilkan kisaran nilai mulai dari 80 sampai dengan 100 seperti tertera pada gambar 2 .

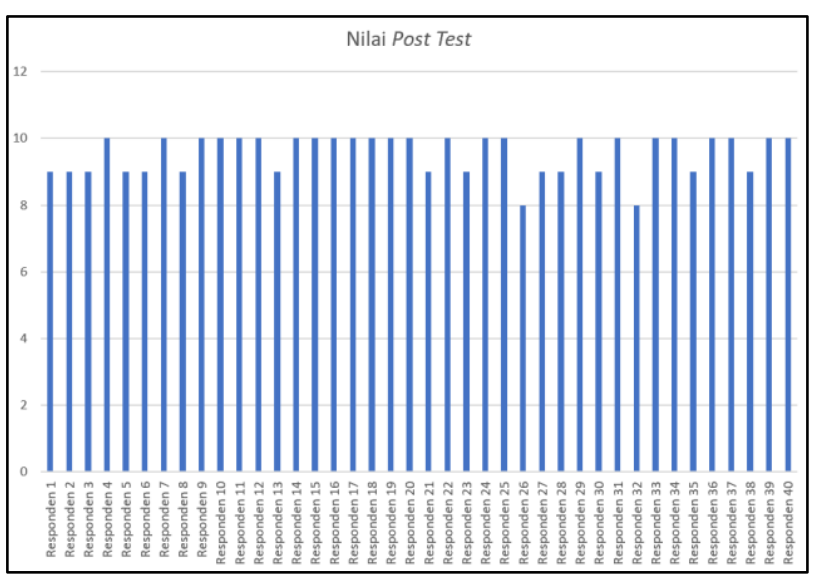

Gambar 2: Nilai Post Test Peserta

Selain itu nilai akhir yang didapatkan peserta juga cukup baik dengan capaian seluruh peserta lulus dengan nilai minimal dalam kategori memuaskan. Seluruh peserta mampu melampaui batas minimal nilai yang harus dicapai dalam ujian komprehensif yang telah diselenggarakan.

Pencapaian tujuan pembelajaran dari sisi knowledge ini didukung dengan keunggulan dalam pembelajaran e-learning yang sulit didapatkan dalam pembelajaran klasikal. Kemudahan tersebut diantaranya ketersediaan materi seperti video dan data lain yang dapat diakses sewaktu-waktu di LMS. Keleluasaan waktu dalam belajar seperti yang diskusi melalui media whatsapp group maupun telegram yang tidak terbatas. Selain itu keberagaman media yang dapat digunakan sehingga mengurangi rasa bosan bahkan meningkatkan motivasi belajar. Kemudahan tersebut merangsang peserta untuk terus menggali secara mendalam setiap materi yang dipelajarinya.

Dari sisi skill atau keterampilan yang dicapai, peserta mampu menguasai bidang ini dengan baik. Sebagai contoh adalah keterampilan dalam membuat tulisan berupa rancangan kegiatan aktualisasi dan laporan kegiatan aktualisasi. Peserta mampu menyelesaikannya dengan minimal penilaian dalam kategori memuaskan. Selain itu peserta juga dapat 
menyelesaikan setiap tugas yang diberikan oleh pengampu materi dengan baik.

Sementara itu dari sisi attitude atau sikap, peserta telah menunjukkan perilaku yang sesuai dengan yang diharapkan dalam pembelajaran. Nilai-nilai yang ditanamkan dalam kelas sebagai upaya pembentukan karakter peserta terlihat dalam perilaku peserta dalam kegiatan sehari-hari. Pengamatan dilakukan pada saat peserta berada di kelas daring yang senantiasa bersiap dan sopan selama mengikuti proses pembelajaran. Selain itu pada saat penyelesaian tugas kelompok juga tercermin perilaku kerjasama dan sikap saling menghargai serta menghormati yang lainnya. Testimoni para mentor juga mendukung mengenai perilaku positif para peserta selama melakukan kegiatan habituasi di tempat kerja. Selain itu penyelenggara sebagai pendamping selama pelaksanaan pembelajaran e-learning pada Latsar CPNS berlangsung juga memberikan nilai baik.

\section{b. Kemampuan memberikan pengalaman belajar yang menarik.}

Untuk mengetahui keberhasilan pembelajaran e-leaning pada Latsar CPNS dalam hal kemampuan memberikan pengalaman yang menarik pada peserta dapat dilihat berdasarkan data pada gambar 3.

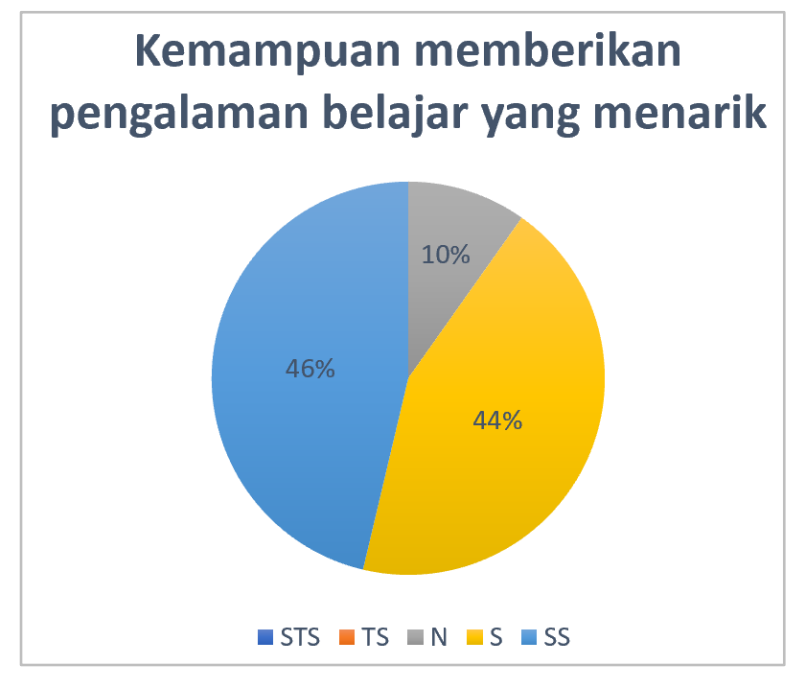

\section{Gambar 3. Kemampuan memberikan pengalaman belajar yang menarik}

Kondisi yang menggambarkan pengalaman belajar yang menarik selama mengikuti pembelajaran e-learning terlihat dari data bahwa peserta menyatakan $10 \%$ netral, $46 \%$ setuju dan $44 \%$ sangat setuju. Hal ini karena materi disampaikan melalui berbagai metode yang beragam dan cukup interaktif.

Metode yang diterapkan dalam penyampaian materi tidak hanya melalui ceramah yang cenderung monoton dan kadang membuat jenuh. Beberapa metode penyampaian lainnya seperti tanya jawab juga sering diterapkan. Beberapa pengajar juga mengombinasikan metode lain dengan memanfaatkan teknologi sehingga penyampaian materi terasa lebih menarik seperti games, brainstorming dan diskusi kelompok.

Untuk memperdalam pemahaman terhadap materi juga diterapkan metode penugasan dalam bentuk pembuatan poster maupun video serta bentuk lainnya sehingga mengurangi rasa bosan selama proses belajar. Peserta juga sangat senang saat pengajar menyampaikan materi dengan mengikutsertakan keaktifan peserta melalui metode presentasi dan windows shopping.

Dengan penggunaan berbagai macam metode penyampaian materi selama proses pembelajaran tersebut, peserta merasakan dinamika dalam proses memahami materi. Selanjutnya beragam metode belajar yang menarik mampu memberikan pengalaman baru yang menantang dan membuat kelas menjadi dinamis, sehingga peserta (83\%) merasa senang dan berharap pada kesempatan lainnya saat pelatihan daring dilakukan model penyampaian materi dengan metode pembelajaran serupa.

\section{c. Mampu melibatkan peserta secara aktif.}

Untuk mengetahui keberhasilan daring dalam melibatkan peserta secara aktif pada Latsar CPNS dapat dilihat berdasarkan data pada gambar 4 . 
Mampu melibatkan peserta secara aktif



ETS $=\mathrm{TS}=\mathrm{N}=\mathrm{S}=\mathrm{SS}$

Berdasarkan data di atas diperoleh gambaran bahwa $56 \%$ responden menjawab setuju dan $17 \%$ sangat setuju bahwa kegiatan pembelajaran melalui daring telah mampu mengajak peserta untuk berpartisipasi secara aktif. Hal ini disebabkan peserta banyak dilibatkan dalam setiap sesi pembelajaran dengan penggunaan berbagai metode pembelajaran yang diterapkan maupun melalui berbagai aplikasi media digital yang tersedia.

Secara umum pembelajaran e-learning ini dilakukan dengan dua model yaitu synchronous dan asynchronous. Berdasarkan observasi dan wawancara didapatkan informasi bahwa peserta lebih menyukai model synchronous dibandingkan asynchronous.

Terdapat beberapa alasan yang menyebabkan peserta menyukai synchronous diantaranya yaitu peserta sangat senang pada saat dilibatkan dalam diskusi atau curah pendapat terkait substansi materi yang disampaikan yang dilakukan melalui tatap muka secara daring. Selain itu penyampaian materi yang disampaikan secara tatap muka secara daring juga mampu menarik peserta untuk terlibat langsung dalam mendengarkan penjelasan dari pengajar serta melakukan tanya jawab secara langsung. Hal ini dikarenakan metode tatap muka daring membuat materi lebih jelas dan komprehensif, sehingga komunikasi dua arah antara pengajar

dengan peserta dapat berlangsung dengan mudah.

Hal lain yang membuat peserta merasa terlibat langsung selama tatap muka daring adalah peserta merasa dapat lebih fokus dan bersemangat dalam belajar, sehingga peserta mengharapkan agar model pembelajaran synchronous porsinya lebih banyak dibandingkan dengan asynchronous. Peserta juga merasa dapat berperan aktif melalui games dan presentasi. Metode tersebut selain menarik juga memaksa peserta untuk berperan secara langsung dalam proses pembelajaran. Peserta juga merasa berpartisipasi aktif pada saat menggunakan berbagai jenis aplikasi seperti youtube, quizizz, kahoot, dan sebagainya. Video yang disaksikan melalui youtube sangat bervariasi dan menambah pengayaan pengetahuan. Selama belajar, gamifikasi melalui quizizz dan kahoot juga mampu menarik peserta untuk mengikutinya.

\section{d. Sarana terpenuhi dengan baik sehingga menunjang proses belajar mengajar.}

Untuk mengetahui keberhasilan dalam pemenuhan sarana yang menunjang proses belajar, penulis telah melakukan survei dengan hasil dapat dilihat pada gambar 5 .

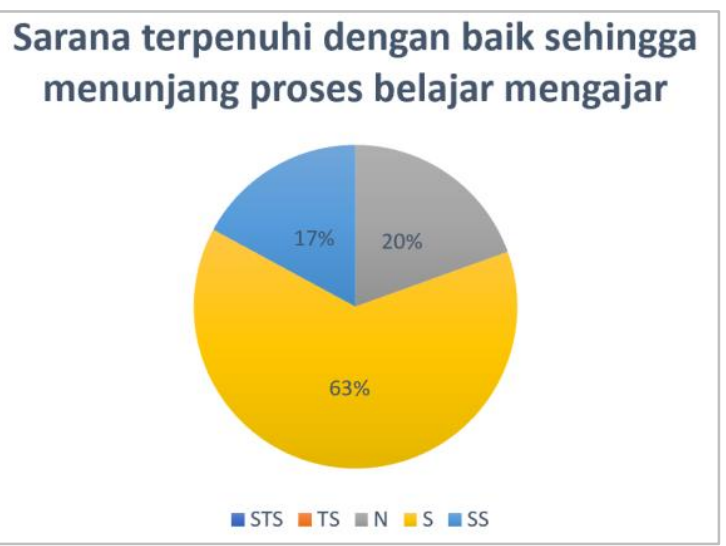

Gambar 5. Sarana terpenuhi dengan baik sehingga menunjang proses belajar mengajar

Berdasarkan gambar 5 dapat diketahui bahwa $63 \%$ responden menjawab setuju dan $17 \%$ sangat setuju bahwa sarana yang menunjang 
proses pembelajaran pada Latsar CPNS terpenuhi dengan baik. Sarana tersebut baik yang bersifat fisik maupun non fisik.

Salah satu sarana fisik yang digunakan dalam pembelajaran e-learning adalah ruang untuk mengajar online. Meskipun ruang tersebut belum disediakan secara khusus namun ruang yang tersedia dapat berfungsi sebagai ruang mengajar dengan baik. Sarana fisik lainnya yaitu berupa hardware. Penyediaan komputer untuk pengajar dan penyelenggara dapat dipenuhi dengan baik meskipun belum maksimal.

Sedangkan sarana non fisik yang telah disediakan dalam pembelajaran e-learning berupa bandwith yang memadai dan software atau aplikasi terkait yang dibutuhkan dalam daring. Selama proses pembelajaran e-learning dilakukan dengan lokasi di area kantor Pusdiklat BSSN, peserta menggunakan bandwith yang telah disediakan oleh penyelenggara. Sedangkan proses pembelajaran e-learning yang dilakukan di luar area kantor Pusdiklat menggunakan bandwith secara swadaya dari pengajar, penyelenggara maupun peserta. Namun demikian secara umum kebutuhan tersebut dapat terpenuhi dengan baik.

Sementara itu beberapa software atau aplikasi yang disediakan dalam daring adalah LMS sebagai sarana pembelajaran asynchronous. Sarana lainnya adalah zoom dan sejenisnya sebagai media tatap muka secara online atau synchronous. Selain itu aplikasi pesan instan seperti telegram dan whatsapp juga digunakan untuk mendukung komunikasi antara pengajar, peserta maupun penyelenggara pelatihan.

Secara umum pembelajaran e-learning yang dilaksanakan telah berjalan secara efektif. Namun demikian terdapat beberapa hal yang perlu dilakukan untuk perbaikan seperti penyediaan sarana monitoring sikap perilaku peserta. Pada pembelajaran konvensional pemantuan sikap dan tingkah laku ini dapat dilakukan oleh pendamping melalui kegiatan senam pagi, apel, makan bersama, dan lainlain sebagaimana kehidupan sehari-hari di asrama.
Selain penyampaian materi dengan metode gamifikasi, pembelajaran perlu ditingkatkan untuk meningkatkan peran aktif peserta. Gamifikasi juga mampu membuat peserta merasa tertarik dan mengurangi rasa bosan selama proses belajar.

Faktor lain yang perlu dipertimbangkan dalam pembelajaran e-learning ini adalah kesehatan peserta. Selama pembelajaran e-learning pada Latsar CPNS tidak ada agenda khusus untuk kegiatan olah raga bersama yang dapat dipantau langsung oleh penyelenggara. Beberapa peserta merasa kelelahan secara fisik terutama pada organ mata pada saat harus menatap layar monitor dalam waktu relatif panjang selama proses pembelajaran elearning.

\section{KESIMPULAN}

Berdasarkan pembahasan, penulis menyimpulkan bahwa pembelajaran elearning pada Latsar CPNS berjalan secara efektif. Hal ini dapat diketahui dari beberapa indikator efektivitas pembelajaran dalam pelatihan yang telah terpenuhi baik dari aspek keberhasilan dalam mengantarkan peserta mencapai tujuan instruksional yang telah di tetapkan, aspek kemampuan memberikan pengalaman belajar yang atraktif, dan aspek kemampuan melibatkan siswa secara aktif sehingga menunjang pencapaian tujuan instruksional. Hasil lain menunjukkan bahwa pembelajaran e-learning pada Latsar CPNS dengan model synchronous lebih diminati dibandingkan dengan asynchronous karena membantu peserta untuk fokus dan meningkatkan motivasi dalam belajar.

Sebagai saran untuk perbaikan pelaksanaan pembelajaran e-learning pada Latsar CPNS, penulis merekomendasikan untuk memberbanyak porsi waktu pembelajaran synchronous dan peningkatan variasi metode penyampaian materi terutama yang bersifat gamifikasi. Sedangkan dari pemenuhan sarana prasarana perlu disiapkan ruang mengajar dengan konsep pembelajaran e-learning dan pemenuhan bandwith yang dibutuhkan selama proses pembelajaran. 


\section{REFERENSI}

Chusna, N. L. (2019). Pembelajaran E-learning. Prosiding Seminar Nasional Pendidikan (hal. 2). Jakarta: KALUNI.

Badu, S. Q. (2012). Implementasi Evaluasi Model Kirkpatrick Pada Perkuliahan Masalah Nilai Awal Dan Syarat Batas the Implementation of Kirkpatrick'S Evaluation Model in the Learning of Initial Value and Bondary Condition Problems. Jurnal Penelitian Dan Evaluasi Pendidikan, 16, 102-129

Clark, D. L. (2007). The ELearning Guild's Handbook on Synchronous e-learning. Santa Rosa: David Holcombe.

Firman, H. (1987). Ilmu dan Aplikasi Pendidikan. Bandung: ITB.

Hartley, D. E. (2001). Selling e-learning American Society for Training and Development. United State of America: ASTD.

Lembaga Administrasi Negara Republik Indonesia, Peraturan Nomor 10 Tahun 2018 Tentang Pedoman Pengembangan Kompetensi Pegawai Negeri Sipil

Mahmudi, I. (2011). CIPP: Suatu Model Evaluasi Program Pendidikan. Jurnal At-Ta'dib, 6(1), 118.

Malik, G. F. (2017). E-learning: Students' Perspectives about Asynchronous and. Bulletin of Education and Research, 183-195.

Munir, R. (2017). Pembelajaran Digital. Bandung: Alfabeta.

Pranoto, A. (2009). Sains dan Teknologi. Jakarta: P.T. Gramedia Pustaka Utama.

Rahman, M. A., Amarullah, R., \& Hidayah, K. (2020). Evaluasi Penerapan Model Pembelajaran ELearning pada Pelatihan Dasar Calon Pegawai Negeri Sipil. Jurnal Borneo Administrator, 16(1), 101-116. https://doi.org/10.24258/jba.v16il.656

Pemerintah Republik Indonesia, Peraturan Nomor 11 Tahun 2017 tentang Manajemen PNS.

Rosenberg. (2001). E-learning: Strategies for delivering knowledge in the digital age. New York: Mc Graw-Hill.

Sugiyono. (2012). Metode Penelitian Kuantitatif Kualitatif dan R\&B. Bandung: Alfabeta.

Suharsono, A. (2020). Pembelajaran Daring Latsar CPNS From Home dalam Masa Pandemi Covid19. SAP (Susunan Artikel Pendidikan), 5(1). https://doi.org/10.30998/sap.v5i1.6420

Taplin, K. \&. (2013). Who pays for blended learning? A cost benefit analysis. The Internet and Higher Education, 61-68.

Tseng, M. L. (2011). Evaluating the effectiveness of elearning system in uncertainty. Industrial Management and Data Systems, 111 (Emerald Group Publishing Limited), 869-889.

Badu, S. Q. (2012). Implementasi Evaluasi Model Kirkpatrick Pada Perkuliahan Masalah Nilai
Awal Dan Syarat Batas the Implementation of Kirkpatrick'S Evaluation Model in the Learning of Initial Value and Bondary Condition Problems. Jurnal Penelitian Dan Evaluasi Pendidikan, 16, 102-129.

Mahmudi, I. (2011). CIPP: Suatu Model Evaluasi Program Pendidikan. Jurnal At-Ta'dib, 6(1), 118.

Rahman, M. A., Amarullah, R., \& Hidayah, K. (2020). Evaluasi Penerapan Model Pembelajaran ELearning pada Pelatihan Dasar Calon Pegawai Negeri Sipil. Jurnal Borneo Administrator, 16(1), 101-116. https://doi.org/10.24258/jba.v16il.656

Republik Indonesia, P. P. R. I. (2017). Pp 11 2017. 10, $11-18$.

Suharsono, A. (2020). Pembelajaran Daring Latsar CPNS From Home dalam Masa Pandemi Covid-19. SAP (Susunan Artikel Pendidikan), 5(1). https://doi.org/10.30998/sap.v5i1.6420 